\title{
Antimicrobial activity of metal oxide nanoparticles against Gram-positive and Gram-negative bacteria: a comparative study
}

This article was published in the following Dove Press journal:

International Journal of Nanomedicine

4 December 2012

Number of times this article has been viewed

\author{
Ameer Azam ${ }^{1,2}$ \\ Arham S Ahmed ${ }^{2}$ \\ Mohammad Oves ${ }^{3}$ \\ Mohammad S Khan ${ }^{3}$ \\ Sami S Habib' \\ Adnan Memic' \\ 'Centre of Nanotechnology, King \\ Abdulaziz University, Jeddah, Saudi \\ Arabia; ${ }^{2}$ Centre of Excellence in \\ Materials Science (Nanomaterials), \\ ${ }^{3}$ Department of Agricultural \\ Microbiology, Aligarh Muslim \\ University, Aligarh, India
}

Correspondence: Ameer Azam Centre of Nanotechnology, King Abdulaziz University, Abdullah Sulayman, Jeddah 22254, Saudi Arabia Email azam222@rediffmail.com
Background: Nanomaterials have unique properties compared to their bulk counterparts. For this reason, nanotechnology has attracted a great deal of attention from the scientific community. Metal oxide nanomaterials like $\mathrm{ZnO}$ and $\mathrm{CuO}$ have been used industrially for several purposes, including cosmetics, paints, plastics, and textiles. A common feature that these nanoparticles exhibit is their antimicrobial behavior against pathogenic bacteria. In this report, we demonstrate the antimicrobial activity of $\mathrm{ZnO}, \mathrm{CuO}$, and $\mathrm{Fe}_{2} \mathrm{O}_{3}$ nanoparticles against Gram-positive and Gram-negative bacteria.

Methods and results: Nanosized particles of three metal oxides $\left(\mathrm{ZnO}, \mathrm{CuO}\right.$, and $\left.\mathrm{Fe}_{2} \mathrm{O}_{3}\right)$ were synthesized by a sol-gel combustion route and characterized by X-ray diffraction, Fourier-transform infrared spectroscopy, and transmission electron microscopy techniques. X-ray diffraction results confirmed the single-phase formation of all three nanomaterials. The particle sizes were observed to be 18,22 , and $28 \mathrm{~nm}$ for $\mathrm{ZnO}, \mathrm{CuO}$, and $\mathrm{Fe}_{2} \mathrm{O}_{3}$, respectively. We used these nanomaterials to evaluate their antibacterial activity against both Gram-negative (Escherichia coli and Pseudomonas aeruginosa) and Gram-positive (Staphylococcus aureus and Bacillus subtilis) bacteria.

Conclusion: Among the three metal oxide nanomaterials, $\mathrm{ZnO}$ showed greatest antimicrobial activity against both Gram-positive and Gram-negative bacteria used in this study. It was observed that $\mathrm{ZnO}$ nanoparticles have excellent bactericidal potential, while $\mathrm{Fe}_{2} \mathrm{O}_{3}$ nanoparticles exhibited the least bactericidal activity. The order of antibacterial activity was demonstrated to be the following: $\mathrm{ZnO}>\mathrm{CuO}>\mathrm{Fe}_{2} \mathrm{O}_{3}$.

Keywords: nanomaterial, $\mathrm{ZnO}, \mathrm{CuO}, \mathrm{Fe}_{2} \mathrm{O}_{3}$, antibacterial activity, metal oxides

\section{Introduction}

The emergence of infectious diseases in general poses a serious threat to public health worldwide, especially with the emergence of antibiotic-resistant bacterial strains. Generally, both Gram-positive and Gram-negative bacterial strains are thought to present a major public health problem. Over the years, antibiotics have been used to control infections resulting from both community and hospital environments. ${ }^{1-3}$ Current advances in the field of nanobiotechnology, particularly the ability to prepare metal oxide nanomaterials of specific size and shape, are likely to lead to the development of new antibacterial agents. The functional activities of nanoparticles are influenced largely by the particle size. Therefore, nanoparticles have received great attention due to their unique physical, chemical, and effective biological properties in various fields, including medicine. The properties of nanoparticles can easily be altered by reducing or changing their size, especially when the manipulations are done at the 
nanometer scale. ${ }^{4-7}$ Similarly, tailoring of materials at the atomic level in order to attain unique properties has been widely reported. Considering these unique properties, nanosized organic and inorganic particles are being generated for ultimate use in medical practices, such as metal oxides of zinc, copper, and iron in biomedical research. ${ }^{8,9}$ In addition, nanoparticles with smaller particle size have been reported to show good antimicrobial activity. ${ }^{10}$ Antimicrobial activity of nanoparticles has largely been studied with human pathogenic bacteria such as Escherichia coli ${ }^{11}$ and Staphylococcus aureus. ${ }^{12}$ Moreover, these microbes seem to be highly sensitive to $\mathrm{ZnO}$ and $\mathrm{CuO}$ nanoparticles. ${ }^{10,13}$ Bactericidal activity of such nanoparticles in part depends on (1) size, (2) stability, and (3) concentration in the growth medium. While growing in medium amended with nanoparticles, the bacterial population growth can be inhibited by specific nanoparticle interactions. ${ }^{7}$ In general, bacterial cell size is in the micrometer range, while its outer cellular membranes have pores in the nanometer range. Since nanoparticles can be smaller in size than bacterial pores, they will have a unique ability of crossing the cell membrane. There lies a strong challenge in preparing metal oxide nanomaterials stable enough to restrict bacterial growth significantly while in nutrient medium.

In comparison to published reports on physical and chemical properties, very limited information is available on the antimicrobial properties of metal oxide nanoparticles. Realizing the potential antimicrobial applications of metal oxide nanoparticles, we designed experiments to synthesize $\mathrm{ZnO}, \mathrm{CuO}$, and $\mathrm{Fe}_{2} \mathrm{O}_{3}$ nanoparticles using a gel-combustion method and subsequently tested their antibacterial activities against both Gram-positive (S. aureus and Bacillus subtilis) and Gram-negative (Pseudomonas aeruginosa and E. coli) bacterial strains. Furthermore, the antibacterial behavior of these metal oxide nanoparticles was compared.

\section{Materials and methods}

\section{Synthesis and characterization}

In a typical synthesis procedure, metal nitrates of $\mathrm{Zn}, \mathrm{Cu}$, and $\mathrm{Fe}$ and citric acid were dissolved in distilled water with a molar ratio of $1: 1$. The solutions were stirred with a magnetic stirrer at $100^{\circ} \mathrm{C}$. Stirring continues till the formation of gel for approximately 2 hours. As the gel was formed, it was allowed to burn at $200^{\circ} \mathrm{C}$. A light fluffy mass was obtained as a result of combustion, which was further annealed at $400^{\circ} \mathrm{C}$ for 1 hour to obtain the respective crystalline metal oxide nanoparticles. ${ }^{14}$ The metal oxide nanoparticles thus obtained were characterized by X-ray diffraction (XRD), Fouriertransform infrared (FTIR) spectroscopy, and transmission electron microscopy (TEM). Crystallinity, structure, and crystallite size of nanoparticles were determined by XRD using a Rigaku (Tokyo, Japan) Miniflex X-ray diffractometer with $\mathrm{Cu}-\mathrm{K} \alpha$ radiations $(\lambda=0.15406 \mathrm{~nm})$ in the $2 \theta$ range from $20^{\circ}$ to $80^{\circ}$. FTIR spectra of the samples were obtained using a PerkinElmer (Waltham, MA) FTIR spectrophotometer in the $\mathrm{KBr}$ matrix. TEM analysis was carried out using a $200 \mathrm{kV}$ JEOL (Tokyo, Japan) transmission electron microscope.

\section{Determination of antibacterial activity by well-diffusion method}

Antimicrobial activities of the synthesized metal oxide nanoparticles were performed against both Gram-negative (E. coli and P. aeruginosa) and Gram-positive (B. subtilis and $S$. aureus) bacteria. The antibacterial activity was done by modified Kirby-Bauer disk diffusion method. ${ }^{15}$ In brief, the pure cultures of organisms were subcultured in MüllerHinton broth at $35^{\circ} \mathrm{C} \pm 2^{\circ} \mathrm{C}$ on a rotary shaker at $160 \mathrm{rpm}$. For bacterial growth, a lawn of culture was prepared by spreading the $100 \mu \mathrm{L}$ fresh culture having $10^{6}$ colony-forming units $(\mathrm{CFU}) / \mathrm{mL}$ of each test organism on nutrient agar plates with the help of a sterile glass-rod spreader. Plates were left standing for 10 minutes to let the culture get absorbed. Then $8 \mathrm{~mm}$ wells were punched into the nutrient agar plates for testing nanomaterial antimicrobial activity. Wells were sealed with one drop of molten agar ( $0.8 \%$ agar) to prevent leakage of nanomaterials from the bottom of the wells. Using a micropipette, $100 \mu \mathrm{L}$ $(50 \mu \mathrm{g})$ of the sample of nanoparticle suspension was poured onto each of five wells on all plates. After overnight incubation at $35^{\circ} \mathrm{C} \pm 2{ }^{\circ} \mathrm{C}$, the different levels of zone of inhibition were measured. Solvent blank was used as negative control. Antibiotic tetracycline was used as a positive control.

\section{Determination of minimal bactericidal concentrations}

Bacterial minimum bactericidal concentration (MBC) for metal oxide nanoparticles was determined by the brothdilution method. ${ }^{16}$ In the present experiment, we used both Gram-positive and Gram-negative bacterial strains. Control experiments were also carried out in the presence of known standard antibiotics (tetracycline). A $10 \mathrm{~mL}$ nutrient broth medium amended with metal oxide nanomaterials $(10-100 \mu \mathrm{g} / \mathrm{mL})$ was prepared separately. Each set was inoculated aseptically with $100 \mu \mathrm{L}$ of respective bacterial suspension $\left(10^{6} \mathrm{CFU} / \mathrm{mL}\right)$. The inoculated sets were incubated at $35^{\circ} \mathrm{C} \pm 2^{\circ} \mathrm{C}$ for 24 hours. Viable bacterial colonies were counted and recorded by the naked eye determining the lowest concentration that locked bacteria growth, defining 
this as the MBC. The experiments were carried out in triplicate, and averages were reported.

\section{Results}

\section{Morphological analysis}

The typical XRD patterns of the $\mathrm{ZnO}, \mathrm{CuO}$, and $\mathrm{Fe}_{2} \mathrm{O}_{3}$ nanoparticles annealed at $400^{\circ} \mathrm{C}$ are shown in Figure 1. The peak positions of samples exhibit the hexagonal, monoclinic, and rhombohedral structures of $\mathrm{ZnO}, \mathrm{CuO}$, and $\mathrm{Fe}_{2} \mathrm{O}_{3}$, which were confirmed from the International Centre for Diffraction Data card numbers 80-0075, 80-1916, and 85-0987, respectively. Furthermore, no impurity peaks were observed in the XRD patterns, as all of the three metal oxides showed single-phase sample formation. The crystallite size was calculated using the Scherrer formula,

$$
D=\frac{0.9 \lambda}{\beta \cos \theta}
$$

where $\lambda$ is the wavelength of $\mathrm{X}$-ray radiation and $\beta$ is the full width at half maximum of the peaks at the diffracting angle $\theta$. Crystallite sizes were calculated to be $18 \mathrm{~nm}$, $22 \mathrm{~nm}$, and $26.1 \mathrm{~nm}$ for $\mathrm{ZnO}, \mathrm{CuO}$, and $\mathrm{Fe}_{2} \mathrm{O}_{3}$ nanoparticles, respectively.

Figure 2 exhibits TEM images and histograms of particlesize distribution of $\mathrm{ZnO}, \mathrm{CuO}$, and $\mathrm{Fe}_{2} \mathrm{O}_{3}$ nanoparticles sintered at $400^{\circ} \mathrm{C}$. Average particle sizes obtained from TEM images were found to be $19.89 \pm 1.43 \mathrm{~nm}, 29.11 \pm 1.61 \mathrm{~nm}$, and $35.16 \pm 1.47 \mathrm{~nm}$ for $\mathrm{ZnO}, \mathrm{CuO}$, and $\mathrm{Fe}_{2} \mathrm{O}_{3}$ nanoparticles, respectively. The average particle sizes determined by TEM images were very close to the crystallite size calculated from XRD results. Thus, the TEM results correlate well with XRD results.

FTIR spectra were recorded in solid phase using the $\mathrm{KBr}$ pellet technique in the regions of $3500-400 \mathrm{~cm}^{-1}$. FTIR spectra of $\mathrm{ZnO}, \mathrm{CuO}$, and $\mathrm{Fe}_{2} \mathrm{O}_{3}$ nanoparticles are shown in Figure 3 . FTIR spectra of all three metal oxide $\left(\mathrm{ZnO}, \mathrm{CuO}\right.$, and $\left.\mathrm{Fe}_{2} \mathrm{O}_{3}\right)$ nanoparticles exhibited vibrations in the region $400-600 \mathrm{~cm}^{-1}$, which can be attributed to the vibrations of $\mathrm{M}-\mathrm{O}(\mathrm{M}=\mathrm{Zn}$, $\mathrm{Cu}$, and $\mathrm{Fe}$ ) which confirms the formation of $\mathrm{ZnO}, \mathrm{CuO}$ and $\mathrm{Fe}_{2} \mathrm{O}_{3}$ nanoparticles. A weak band at around $2300 \mathrm{~cm}^{-1}$ may be attributed to the vibrations of atmospheric $\mathrm{CO}_{2}$. In the case of $\mathrm{Fe}_{2} \mathrm{O}_{3}$, the bands appearing at $1632 \mathrm{~cm}^{-1}$ can be attributed to the angular deformation of water $\delta \mathrm{H}-\mathrm{OH}$, while the band appearing at $3436 \mathrm{~cm}^{-1}$ can be assigned to the $\mathrm{O}-\mathrm{H}$ stretching of water. The present findings agree well with the values reported in the available literature. ${ }^{17-21}$

\section{Antimicrobial properties}

Antibacterial activity results revealed that $\mathrm{ZnO}$ and $\mathrm{CuO}$ nanoparticles acted as excellent antibacterial agents against both Gram-positive and Gram-negative bacteria when

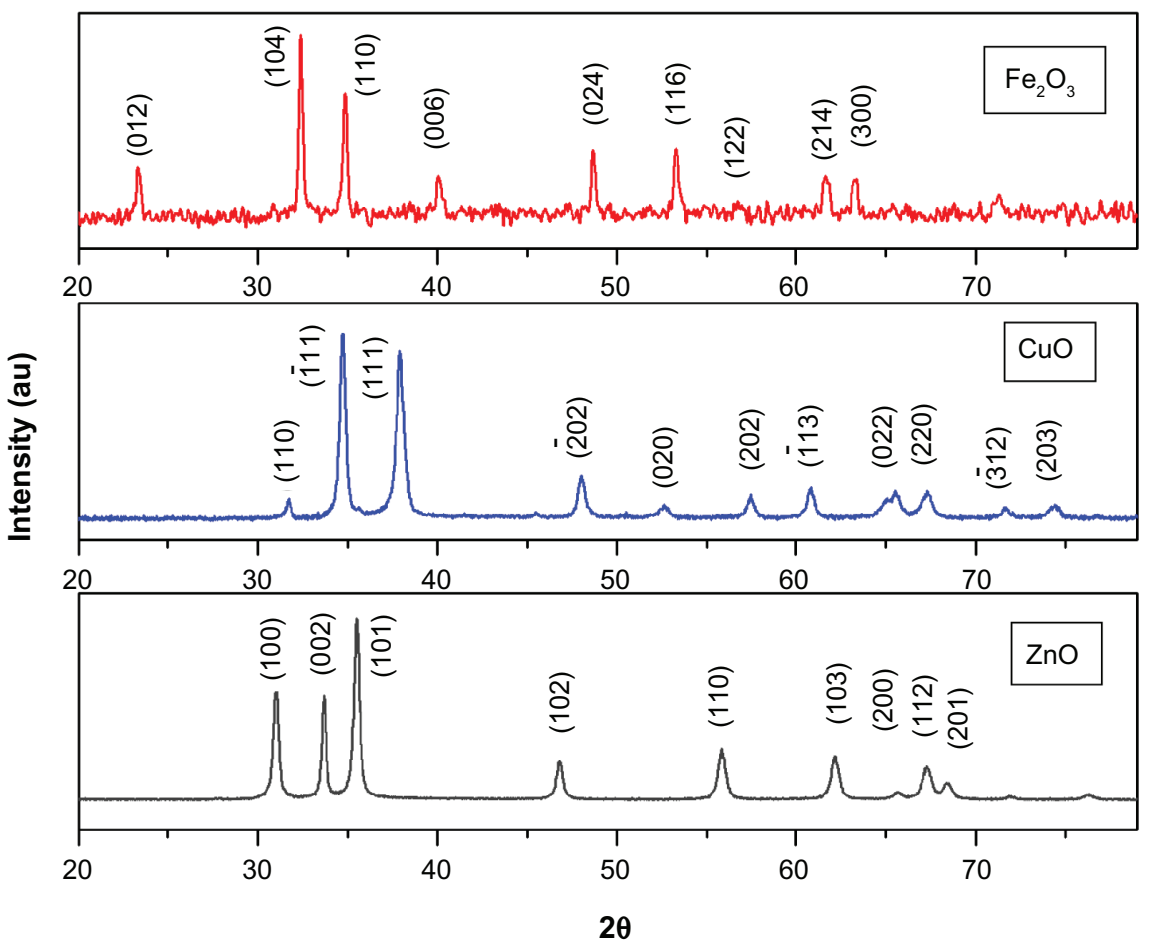

Figure I X-ray diffraction spectra of $\mathrm{ZnO}, \mathrm{CuO}$, and $\mathrm{Fe}_{2} \mathrm{O}_{3}$ nanoparticles. 

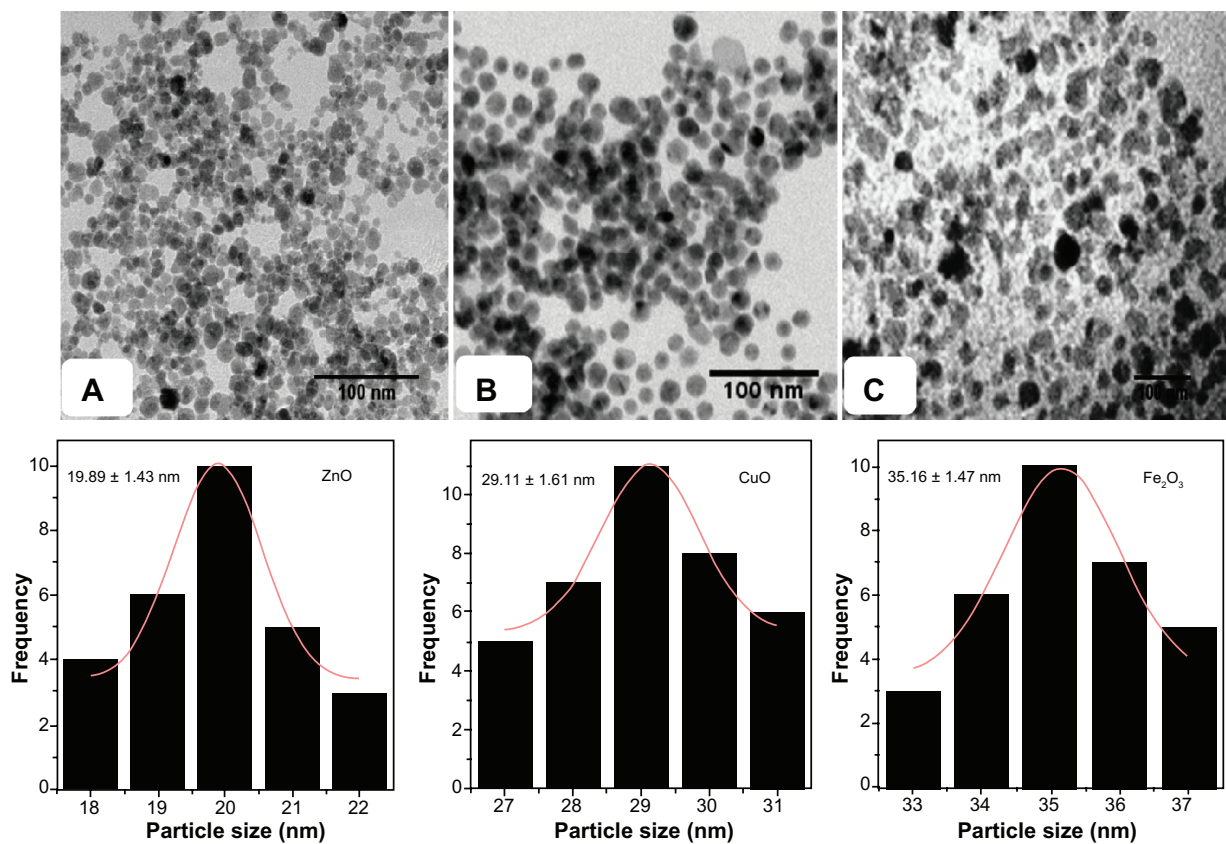

Figure 2 Transmission electron microscopy images of $(\mathbf{A}) \mathrm{ZnO}$, (B) $\mathrm{CuO}$, and (C) $\mathrm{Fe}_{2} \mathrm{O}_{3}$ nanoparticles and histogram of particle-size distribution for different metal oxide nanoparticles.

compared to $\mathrm{Fe}_{2} \mathrm{O}_{3}$ nanoparticles. It is clear from the XRD and TEM results that $\mathrm{ZnO}$ nanoparticles are smaller in size compared to $\mathrm{CuO}$ and $\mathrm{Fe}_{2} \mathrm{O}_{3}$. Figure 4 shows the zone of inhibition produced by different metal oxide nanoparticles against both Gram-positive and Gram-negative bacterial strains. $\mathrm{ZnO}(19.89 \pm 1.43 \mathrm{~nm})$ nanoparticles exhibited maximum
(25 mm) bacterial growth inhibition against $B$. subtilis, in the form of zone-of-inhibition studies, where diffusion of nanoparticles on nutrient agar plates inhibits growth. In contrast, $\mathrm{CuO}$ and $\mathrm{Fe}_{2} \mathrm{O}_{3}$ showed zones of inhibition of 21 and $15 \mathrm{~mm}$, respectively, against $B$. subtilis. In the case of E. coli maximum growth, inhibition zones were found to be

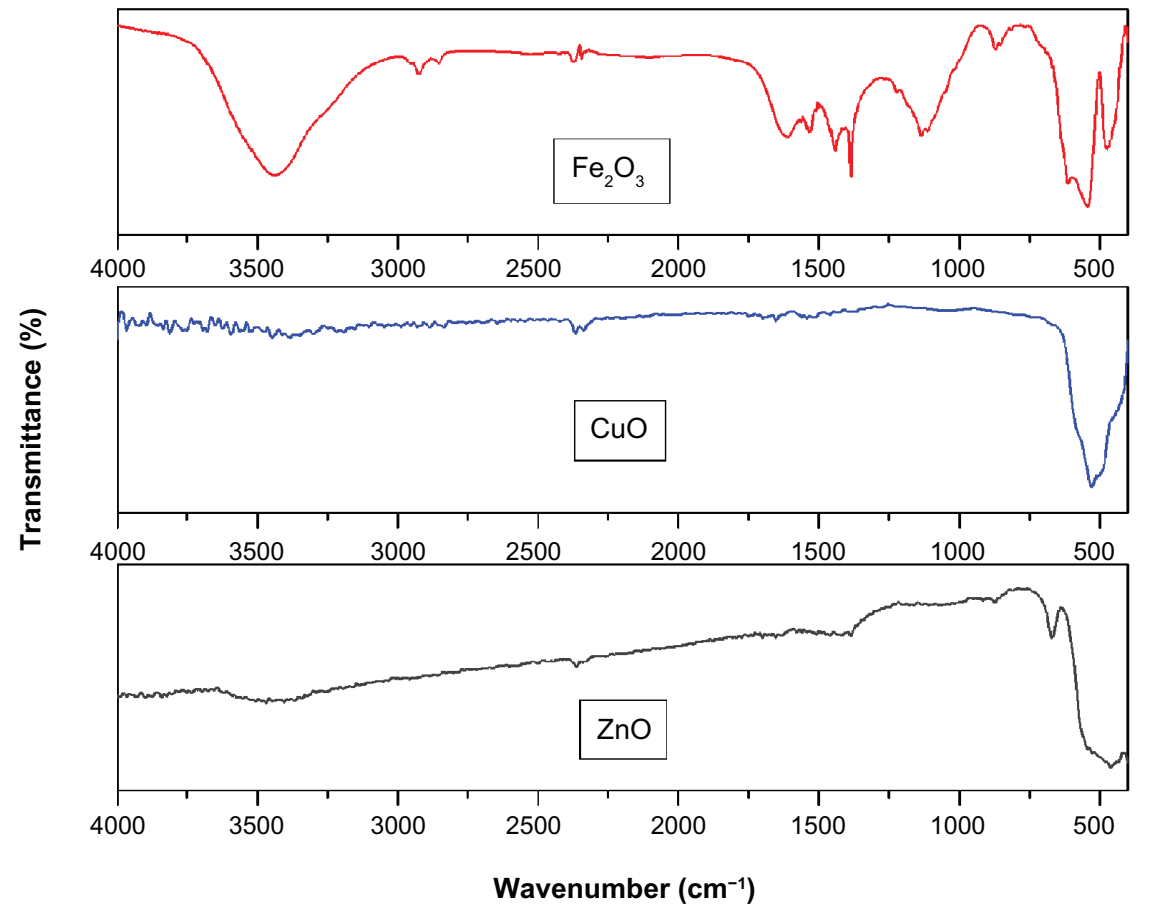

Figure 3 Fourier-transform infrared spectra of $\mathrm{ZnO}, \mathrm{CuO}$, and $\mathrm{Fe}_{2} \mathrm{O}_{3}$ nanoparticles. 


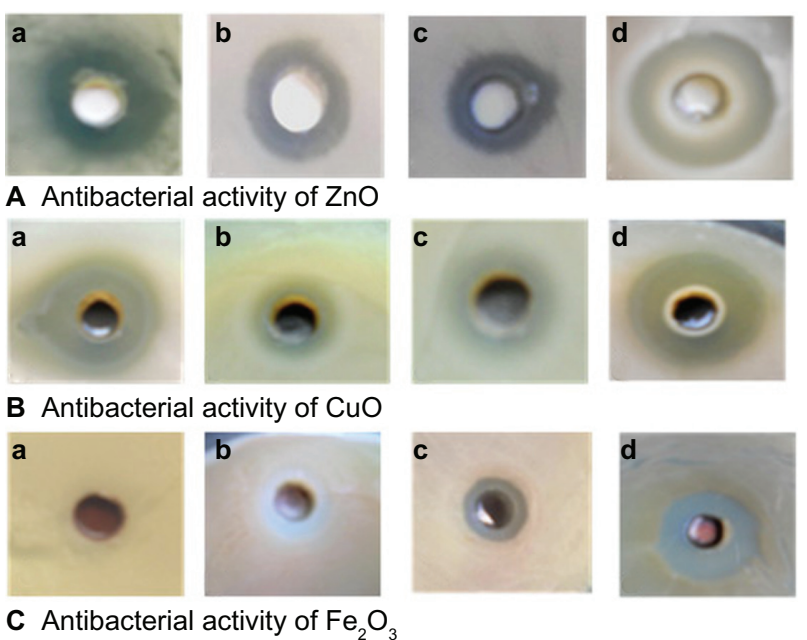

Figure 4 Zone of inhibition produced by different metal oxide nanoparticles against both $\mathrm{Gram}$-positive and Gram-negative bacterial strains. Antibacterial activity of (A) $\mathrm{ZnO}$; (B) $\mathrm{CuO}$; and (C) $\mathrm{Fe}_{2} \mathrm{O}_{3}$ of bacterial strains (a), Escherichia coli, (b) Staphylococcus aureus, (c) Pseudomonas aeruginosa, and (d) Bacillus subtilis.

the following; 19, 15, and $3 \mathrm{~mm}$ for $\mathrm{ZnO}, \mathrm{CuO}$, and $\mathrm{Fe}_{2} \mathrm{O}_{3}$, respectively (Figure 5). Similar patterns were observed in the case of P. aeruginosa and $S$. aureus, where the maximum zone of inhibition was exhibited by $\mathrm{ZnO}$ followed by $\mathrm{CuO}$ and $\mathrm{Fe}_{2} \mathrm{O}_{3}$. It appears that the antibacterial activity of the nanomaterials increased with increase in surface-to-volume ratio due to the decrease in size of nanoparticles.

\section{Discussion}

We demonstrated that the order of antibacterial activities of nanomaterials was $\mathrm{ZnO}(19.89 \pm 1.43 \mathrm{~nm})>\mathrm{CuO}$ $(29.11 \pm 1.61 \mathrm{~nm})>\mathrm{Fe}_{2} \mathrm{O}_{3}(35.16 \pm 1.47 \mathrm{~nm})$, which indicates the size of the nanoparticles might also play a role in the antibacterial activity of each sample. Similar activity observations have been made for nanoparticles composed of a single metal oxide. ${ }^{6,7,10}$ However, it should also be noticed that Gram-negative bacterial strains of E. coli and

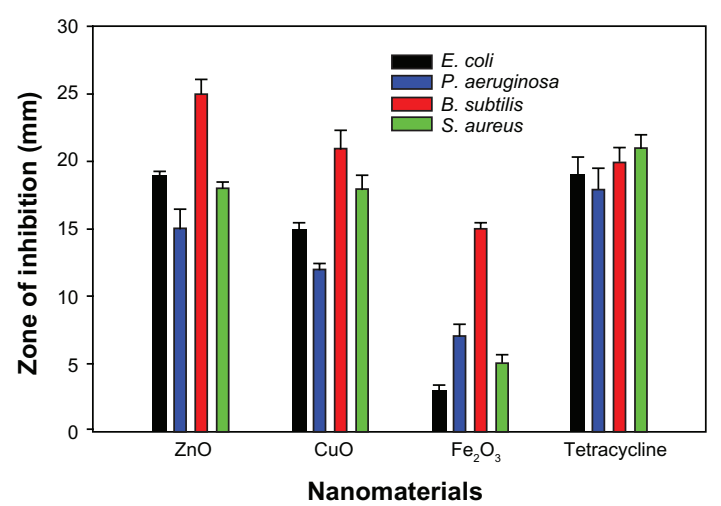

Figure 5 Bar graphs showing zone of inhibition introduced by different metal oxides against various microorganisms.
P. aeruginosa had inhibition-zone sizes that were $24 \%$ and $16 \%$ lower than Gram-positive bacterial strains of B. subtilis and $S$. aureus in the case of $\mathrm{ZnO}$ nanoparticles. And in the case of $\mathrm{CuO}$ nanoparticles, same Gram-negative bacterial strains of $E$. coli and $P$. aeruginosa had zone sizes that were $28 \%$ and $33 \%$ lower than Gram-positive B. subtilis and $S$. aureus bacterial strains, respectively. This observation could also be indicative of higher Gram-negative strain resistance/tolerance against such nanomaterials over Grampositive bacterial strains. Our finding is in agreement with Premanathan et al, who reported that the $\mathrm{ZnO}$ nanoparticle effect is more pronounced against Gram-positive bacterial strains than Gram-negative bacterial strains..$^{22}$

Furthermore, previous studies have shown that the smaller the $\mathrm{ZnO}$ particle size, the greater the efficacy in inhibiting the growth of bacteria, involving both the production of reactive oxygen species and the accumulation of nanoparticles. ${ }^{7,10,23}$ However, nanoparticles of $\mathrm{ZnO}$ were previously reported to act both as bactericidal agents ${ }^{24}$ and bacteriostatic agents, ${ }^{25}$ perhaps thereby limiting their biomedical use.

In another experiment, we analyzed the $\mathrm{MBC}$ of different metal oxide nanoparticles against both Gram-negative and Gram-positive bacterial strains (Table 1). $\mathrm{ZnO}$ nanoparticles were also found to be most bactericidal compared to $\mathrm{Fe}_{2} \mathrm{O}_{3}$ and $\mathrm{CuO}$ nanoparticles. In our $\mathrm{MBC}$ study of $\mathrm{ZnO}$ nanoparticles, $\mathrm{ZnO}$ was $72 \%, 80 \%, 88 \%$, and $84 \%$ more effective than $\mathrm{Fe}_{2} \mathrm{O}_{3}$, while $28 \%, 31 \%, 27 \%, 50 \%$, and $40 \%$ more bactericidal than $\mathrm{CuO}$ against against $E$. coli, $S$. aureus, $P$. aeruginosa, and B. subtilis, respectively. The bactericidal pattern of our synthesized nanomaterials against both Gramnegative and Gram-positive bacterial strains was again $\mathrm{ZnO}>\mathrm{CuO}>\mathrm{Fe}_{2} \mathrm{O}_{3}$. Our results are supported by Baek and $\mathrm{An}^{26}$ and Wang et al, ${ }^{27}$ who reported that $\mathrm{ZnO}$ was the most toxic nanomaterial among ten other nanomaterials. As previously observed with zone-of-inhibition studies, $\mathrm{ZnO}$ nanoparticles had $11 \%$ and $12 \%$ more bactericidal activity against Gram-positive $S$. aureus and B. subtilis than Gram-negative $E$. coli and $P$. aeruginosa, respectively. $\mathrm{CuO}$ nanoparticles were $12 \%$ and $21 \%$ more active against Gram-positive S. aureus and $B$. subtilis than Gram-negative E. coli and P. aeruginosa, respectively. Overall, our observations are that Gram-positive bacterial strains are more sensitive in comparison to Gramnegative strains against the nanomaterials tested.

Thus, in this report, $\mathrm{ZnO}$ nanoparticles have shown the best antibacterial behavior compared to $\mathrm{CuO}$ and $\mathrm{Fe}_{2} \mathrm{O}_{3}$ nanoparticles. However, it is important to identify the key physicochemical properties of nanometal oxides that govern antibacterial activity and cytotoxicity to mammalian cells, 
Table I Minimum bactericidal concentration (MBC) of different metal oxide nanoparticles against Gram-negative and Gram-positive bacteria

\begin{tabular}{|c|c|c|c|c|}
\hline \multirow[t]{2}{*}{ Nanoparticles } & \multicolumn{4}{|c|}{ MBC values $(\mu \mathrm{g} / \mathrm{mL})$} \\
\hline & Escherichia coli & Pseudomonas aeruginosa & Staphylococcus aureus & Baccillus subtilis \\
\hline $\mathrm{ZnO}$ & $18 \pm 0.5$ & $14 \pm 0.6$ & $16 \pm 0.2$ & $12 \pm 0.5$ \\
\hline $\mathrm{CuO}$ & $25 \pm 0.3$ & $28 \pm 0.5$ & $22 \pm 0.5$ & $20 \pm 0.7$ \\
\hline $\mathrm{Fe}_{2} \mathrm{O}_{3}$ & $65 \pm 1.5$ & $120 \pm 2.3$ & $80 \pm 1.5$ & $78 \pm 1.4$ \\
\hline Tetracycline* & $30 \pm 0.4$ & $30 \pm 1.2$ & $28 \pm 1.2$ & $25 \pm 1.5$ \\
\hline
\end{tabular}

Notes: Values are mean of three replicates; *standard antibiotic.

as has been previously initiated. It is essential to assess the contribution of the size, shape, morphology, and electronic properties on cytotoxicity if these particles are to have wide biomedical applications..$^{28,29}$ Our expectation is first to see such nanomaterials applied as surface disinfectants, as their stability would allow long-term storage and prolonged activity.

\section{Conclusion}

The nanosized particles of pure $\mathrm{ZnO}, \mathrm{CuO}$, and $\mathrm{Fe}_{2} \mathrm{O}_{3}$ were synthesized by the sol-gel combustion method. XRD and TEM results showed that $\mathrm{ZnO}$ nanoparticles were smallest $(18 \mathrm{~nm})$ in size compared to $\mathrm{CuO}(22 \mathrm{~nm})$ and $\mathrm{Fe}_{2} \mathrm{O}_{3}$ $(26 \mathrm{~nm})$. Furthermore, the antibacterial activity of all the three synthesized nanomaterials was compared and varied considerably. Antimicrobial activity increased with increase in surface-to-volume ratio due to a decrease in particle size of nanoparticles. Here, $\mathrm{ZnO}$ nanoparticles showed excellent bactericidal potential, while iron oxide nanoparticles had the least bactericidal activity. Our results indicate that nanomaterials were most effective against Gram-positive bacterial strains compared to Gram-negative bacterial strains.

\section{Acknowledgments}

Mr Arham S Ahmed and Mr M Oves are thankful to CSIR, New Delhi, for providing financial support in the form of SRF. Dr Adnan Memic would like to thank the Strategic Technologies Program of King Abdulaziz City for Science and Technology, grant number 10-NAN1081-3, for their partial support and funding of this project.

\section{Disclosure}

The authors report no conflicts of interest in this work.

\section{References}

1. Lowy F. Staphylococcus aureus infections. N Engl J Med. 1998;339: 520-532.

2. Komolafe OO. Antibiotic resistance in bacteria - an emerging public health problem. Malawi Med J. 2003;15:63-67.
3. Hawkey PM. The growing burden of antimicrobial resistance. J Antimicrob Chemother. 2008;62 Suppl 1:i1-i9.

4. Lewis K, Klibanov AM. Surpassing nature: rational design of sterilesurface materials. Trends Biotechnol. 2005;23:343-348.

5. Rosi NL, Mirkin CA. Nanostructures in biodiagnostics. Chem Rev. 2005;105:1547-1562.

6. Azam A, Ahmed AS, Oves M, Khan MS, Memic A. Size-dependent antimicrobial properties of $\mathrm{CuO}$ nanoparticles against Gram-positive and -negative bacterial strains. Int J Nanomedicine. 2012;7:3527-3535.

7. Raghupati KR, Koodali RT, Manna AC. Size-dependent bacterial growth inhibition and mechanism of antibacterial activity of zinc oxide nanoparticles. Langmuir. 2011;27:4020-4028.

8. Mahapatra O, Bhagat M, Gopalakrishnan C, Arunachalam KD. Ultrafine dispersed $\mathrm{CuO}$ nanoparticles and their antibacterial activity. $J$ Exp Nanosci. 2008;3:185-193.

9. Tran N, Mir A, Mallik D, Sinha A, Nayar S, Webster TJ. Bactericidal effects of iron oxide nanoparticles on Staphylococcus aureus. Int $J$ Nanomedicine. 2010;5:277-283.

10. Jones N, Ray B, Ranjit KT, Manna AC. Antibacterial activity of ZnO nanoparticles suspensions on a broad spectrum of microorganisms. FEMS Microbiol Lett. 2008;279:71-76.

11. Yoon KY, Byeon JH, Park JH, Hwang J. Susceptibility constants of Escherichia coli and Bacillus subtilis to silver and copper nanoparticles. Sci Total Environ. 2007;373:572-575.

12. Ruparelia JP, Chatterjee AK, Duttagupta SP, Mukherji S. Strain specificity in antimicrobial activity of silver and copper nanoparticles. Acta Biomater. 2008;4:707-716.

13. Heinlaan M, Ivask A, Blinova I, Dubourguier HC, Kahru A. Toxicity of nanosized and bulk $\mathrm{ZnO}, \mathrm{CuO}$ and $\mathrm{TiO}_{2}$ to bacteria Vibrio fischeri and crustaceans Daphnia magna and Thamnocephalus platyurus. Chemosphere. 2008;71:1308-1316.

14. Jundale DM, Pawar SG, Patil SL, Chougule MA, Godse PR, Patil VB. Effect of annealing on structure, morphology and optoelectronic properties of nanocrystalline $\mathrm{CuO}$ thin films. AIP Conf Proc. 2011;1391: 573-575.

15. Bauer AW, Kirby WMM, Sherris JC, Truck M. Antibiotic susceptibility testing by standardized single disk method. Am J Clin Pathol. 1966;45: 493-496.

16. Wikler MA. Methods for Dilution Antimicrobial Susceptibility Tests for Bacteria That Grow Aerobically: Approved Standard. 5th ed. Wayne, PA: National Committee for Clinical Laboratory Standards (NCCLS); 2000:M7-M5.

17. Arshad M, Azam A, Ahmed AS, Mollah S, Naqvi AH. Effect of Co substitution on the structural and optical properties of $\mathrm{ZnO}$ nanoparticles synthesized by sol-gel route. J Alloys Compd. 2011;509:8378-8381.

18. Jagminas A, Kuzmarskyte J, Niaura G. Electrochemical formation and characterization of copper oxygenous compounds in alumina template from ethanolamine solutions. Appl Surf Sci. 2002;201:129-137.

19. Jagminas A, Niaura G, Kuzmarskyte J, Butkiene R. Surface-enhanced Raman scattering effect for copper oxygenous compounds array within the alumina template pores synthesized by ac deposition from $\mathrm{Cu}$ (II) acetate solution. Appl Surf Sci. 2004;225:302-308. 
20. Zhang YC, Tang JY, Wang GL, Zhang M, Hu XY. Facile synthesis of submicron $\mathrm{Cu}_{2} \mathrm{O}$ and $\mathrm{CuO}$ crystallites from a solid metallorganic molecular precursor. J Cryst Growth. 2006;294:278-282.

21. Ansari SA, Azam A, Naqvi AH. Structural and morphological study of $\mathrm{Fe}_{2} \mathrm{O}_{3}$ nanoparticles. Asian J Res Chem. 2011;4:1638-1642.

22. Premanathan M, Karthikeyan K, Jeyasubramanian K, Manivannan G. Selective toxicity of $\mathrm{ZnO}$ nanoparticles toward Gram-positive bacteria and cancer cells by apoptosis through lipid peroxidation. Nanomedicine. 2011;7:184-192.

23. Salah N, Habib SS, Khan ZH, et al. High-energy ball milling technique for $\mathrm{ZnO}$ nanoparticles as antibacterial material. Int J Nanomedicine. 2011;6:863-869.

24. Xie Y, HeY, Irvin PL, Jin T, Shi X. Antibacterial activity and mechanism of action of zinc oxide nanoparticles against Campylobacter jejuni. Appl Environ Microbiol. 2011;77:2325-2331.
25. Gajjar P, Pettee B, Britt DW, Huang W, Johnson WP, Anderson AJ. Antimicrobial activities of commercial nanoparticles against an environmental soil microbe, Pseudomonas putida KT2440. J Biol Eng. 2009;3:9.

26. Baek Y, An Y. Microbial toxicity of metal oxide nanoparticles $\left(\mathrm{CuO}, \mathrm{NiO}, \mathrm{ZnO}\right.$, and $\left.\mathrm{Sb}_{2} \mathrm{O}_{3}\right)$ to Escherichia coli, Bacillus subtilis, and Streptococcus aureus. Sci Total Environ. 2011;409:1603-1608.

27. Wang Z, Lee Y, Wu B, et al. Anti-microbial activities of aerosolized transition metal oxide nanoparticles. Chemosphere. 2010;80: 525-529.

28. Xu M, Fujita D, Kajiwara S, et al. Contribution of physicochemical characteristics of nano-oxides to cytotoxicity. Biomaterials. 2010;31: 8022-8031.

29. Brayner R. The toxicological impact of nanoparticles. Nano Today. 2008;3:48-55
International Journal of Nanomedicine

\section{Publish your work in this journal}

The International Journal of Nanomedicine is an international, peerreviewed journal focusing on the application of nanotechnology in diagnostics, therapeutics, and drug delivery systems throughout the biomedical field. This journal is indexed on PubMed Central,

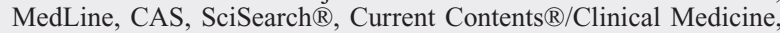

\section{Dovepress}

Journal Citation Reports/Science Edition, EMBase, Scopus and the Elsevier Bibliographic databases. The manuscript management system is completely online and includes a very quick and fair peer-review system, which is all easy to use. Visit http://www.dovepress.com/ testimonials.php to read real quotes from published authors.

Submit your manuscript here: http://www.dovepress.com/international-journal-of-nanomedicine-journal 